\title{
PENGARUH PESTISIDA NABATI MAJA-GADUNG DAN METABOLIT SEKUNDER Trichoderma harzianum TERHADAP HAMA DAN PENYAKIT PADA TOMAT ORGANIK
}

\section{Effect of Stone Apple and Bitter Yam as Botanical Pesticides and T. Harzianum Secondary Metabolites on Pest Insect Populations and Disease Incidence in Organic Tomato Cultivation}

\author{
Agus Suroto*, Mujiono, dan Dina Istiqomah \\ ${ }^{1}$ Fakultas Pertanian, Universitas Jenderal Soedriman
}

Alamat korespondensi: agussuroto@unsoed.ac.id

\begin{abstract}
ABSTRAK
Penelitian ini bertujuan untuk mengetahui pengaruh aplikasi pestisida nabati maja-gadung dan metabolit sekunder Trichoderma harzianum terhadap populasi serangga hama dan insidensi penyakit pada rakitan teknologi budidaya tomat organik. Rancangan yang digunakan ialah Rancangan Acak Kelompok Lengkap (RAKL) dengan 3 perlakuan dan 4 kali ulangan. Perlakuan dalam penelitian ini, yaitu: A (aplikasi pestisida nabati dan metabolit sekunder T. harzianum), B (aplikasi pestisida nabati), dan C (tanpa pengaplikasian/ kontrol). Indeks keanekaragaman Shannon Wiener ditentukan dengan bantuan program PAST. Data kelimpahan serangga hama dan penyakit tanaman yang diperoleh dianalisis dengan uji $\mathrm{F}$, dilanjutkan uji DMRT. Data penyakit ditentukan persentase insidensinya. Hasil penelitian ini menujukkan bahwa secara umum keanekaragaman spesies serangga tergolong sedang (H': 1.24). Bemicia tabaci menjadi spesies hama yang paling melimpah, diikuti Thrips tabaci, dan Myzus persicae. Insidensi penyakit tertinggi terletak pada perlakuan C (13\% layu bakteri), di ikuti perlakuan B (6\% layu bakteri), dan A (2\% layu fusarium dan $2 \%$ layu bakteri).
\end{abstract}

Kata kunci: gadung, keanekaragaman, maja, Trichoderma harzianum

\section{ABSTRACT}

The purpose of this study was to determine the effect of stone apple and bitter yam as botanical pesticides and T. harzianum secondary metabolites on pest insect populations and disease incidence in organic tomato cultivation. The design used was a Complete Randomized Block Design (RCBD) with 3 treatments and 4 replications. The treatments in this study were: A (application of botanical pesticides and T. harzianum secondary metabolites), B (application of botanical pesticides), and C (without application). The analized of Shannon Wiener diversity index was determined with PAST program. Data on the abundance of insect pests and plant diseases obtained were analyzed by the F test dan DMRT test. Incidence percentage of disease was calculated. The results show that insect species diversity was classified as moderate $\left(H^{\prime}: 1.24\right)$. Bemicia tabaci was the most abundant pest species, followed by Thrips tabaci, and Myzus persicae. The highest incidence of disease in treatment $C(13 \%$ bacterial wilting), followed by $B$ ( $6 \%$ bacterial wilting), and A (2\% fusarium wilt and $2 \%$ bacterial wilting).

Keywords: Bitter yam, diversity, stone apple, Trichoderma harzianum

\section{PENDAHULUAN}

Kegiatan pertanian secara organik sekarang ini menjadi arah pertanian baru. Hal tersebut berlandaskan untuk keamanan pangan dan kesehatan lingkungan. Misalnya pada budidaya tomat, Ghorbani et al. (2012) menjelaskan bahwa penerapan sistem pertanian organik dalam budidaya tomat dapat mempengaruhi kualitas buah tomat. Tomat yang dibudidayakan secara organik memiliki kandungan lycopene, asam organik, asam fenol, asam askorbat, vitamin $\mathrm{C}$, vitamin $\mathrm{E}$, zat besi, magnesium dan antioksidan yang lebih tinggi serta memiliki kandungan asam amino esensial yang lebih seimbang dibandingkan dengan 
tomat yang dibudidayakan secara konvensional. Selain itu, keanekaragaman dan kelimpahan arthropoda aktif di permukaan tanah yang tinggi ditemukan pada sawah tanpa diaplikasi insektisida daripada bioinsektisida apalagi insektisida sintetik (Herlinda $d k k$., 2008).

Salah satu wujud kegiatan pertanian organik yang telah dilaksanakan dalam mengendalikan hama maupun penyakit pada budidaya tanaman ialah dengan memanfaatkan buah maja dan umbi gadung, serta metabolit sekunder dari jamur Trichoderma harzianum. Buah maja dan umbi gadung telah banyak digunakan dalam budidaya tanaman sebagai bioinsektisida dalam pengendalian hama. Misalnya, sari pati gadung untuk mengendalikan walang sangit (Rozi dkk., 2018), ulat kantong Pteroma plagiophleps (Utami dan Haneda, 2012), dan penggabungan umbi gadung dan buah maja untuk mengendalikan ulatgrayak Spodoptera litura (Darmanto dkk., 2019).

Permasalah dalam budidaya tanaman juga muncul dengan adanya penyakit yang dapat mengurangi hasil panen. Pada budidaya tomat sering dijumpai penyakit layu bakteri dan layu fusarium yang mampu bertahan lama di dalam tanah. Penanganan penyakit tersebut dilakukan dengan memanfaatkan metabolit sekunder dari jamur Trichoderma harzianum. Alfizar $d k k$. (2011), mengungkapkan bahwa semakin tinggi dosis T. harzianum yang diberikan, maka semakin mampu untuk menekan munculnya patogen layu pada tanaman tomat. Selain itu, perendaman benih tomat pada aplikasi Trichoderma spp. memberikan pengaruh positif terhadap jumlah akar lateral tanaman (Nurahmi $d k k$., 2012).

Namun demikian, belum dijumpai adanya penggabungan secara langsung antara buah maja, umbi gadung dan metabolits sekunder $T$. harzianum untuk mengedalikan hama dan penyakit tanaman. Oleh karenanya, penelitian ini dilakukan untuk mengetahui pengaruh aplikasi pestisida nabati maja-gadung dan metabolit sekunder T. harzianum terhadap populasi serangga hama dan insidensi penyakit pada rakitan teknologi budidaya tomat secara organik, baik secara tunggal maupun gabungan keseluruhan ekstrak.

\section{METODE PENELITIAN}

Penelitian dilaksanakan dengan rancangan acak kelompok lengkap (RAKL) melalui 3 perlakuan rakitan teknologi budidaya tomat organik dan 4 ulangan, yaitu A: Gabungan (Pestisida nabati majagadung + metabolit sekunder Trichoderma harzianum); B: Pestisida nabati majagadung dan C: Kontrol atau tanpa aplikasi (Tabel 1).

Pestisida nabati diperoleh dengan cara membuat secara mandiri ektrak maja-gadung untuk dosis 20 lt/ha. Pestisida 
Tabel 1. Aplikasi pada setiap plot perlakuan

\begin{tabular}{llcc}
\hline \multicolumn{1}{c}{ Komponen Perlakuan } & \multicolumn{3}{c}{ Perlakuan } \\
\cline { 2 - 4 } & $\mathrm{A}$ & $\mathrm{B}$ & $\mathrm{C}$ \\
\hline Pupuk kandang 10/t/Ha & 1 & 1 & 1 \\
Arang sekam 1 ton/ha & 1 & 1 & 1 \\
POC tanah 3 lt/Ha & 1 & 1 & 1 \\
POC daun 3 lt/Ha & 1 & 1 & 1 \\
Pestisida nabati (maja-gadung) 20 lt/ha & 1 & 1 & 0 \\
Metabolit sekunder Trichoderma harzianum (2 lt/ha) & 1 & 0 & 0 \\
\hline
\end{tabular}

Keterangan: 1 (diaplikasikan); 0 (tidak diaplikasikan); setiap perlakuan di ulang sebanyak 4 kali.

nabati dibuat dengan mencampurkan 10 liter air dengan dua butir telur, 10 buah maja, dan 1 liter perasaan gadung. Ektraks tersebut difermentasi secara anaerob selama 14 hari. Selanjutnya, saring ekstrak dan diaplikasikan. Sedangkan, metabolit sekunder yang digunakan merupakan metabolisme sekunder Trichoderma harzianum dari merek dangan Bio-T 10 dengan dosis 2 lt/ha.

Bibit tomat yang disemai dan digunakan pada penelitian ini adalah tanaman tomat varietas Servo. Medium tanaman tomat berupa guludan dengan pemasangan mulsa. Namun sebelumnya dilakukan pencampuran pupuk kandang (10 lt/Ha), dan arang sekam (1 ton/ha) dengan medium tanah. Diaplikasi POC untuk tanah (SO-Kontan Lq) (Aplikasi I) dan dibiarkan selama 10 hari. Pada 2 hari sebelum mulsa dipasang diaplikasikan metabolisme sekunder Trichoderma harzianum (Bio-T 10) (Sesuai perlakuan) dan aplikasi POC untuk tanah (SO-Kontan Lq) (Aplikasi II).
Setelah medium tanam telah siap, bibit pada umur benih 15 hari kemudian ditanaman. Selanjutnya, pada umur 1 minggu setelah tanam diaplikasikan POC untuk daun (SOKontan Lq) dengan teknik pengocoran pada lubang tanam. Pada umur 2 minggu setelah tanam diaplikasikan POC untuk daun (SOKontan Fert) + pestisida nabati. Pada umur 4 minggu setelah tanam diaplikasikan POC untuk daun (SO-Kontan Fert) + pestisida nabati. Sebelum umur 6 minggu dilakukan penyiangan untuk mengurangi gulma pada pertanaman tomat. Pada umur 6 minggu setelah tanam diaplikasikan POC untuk daun (SO-Kontan Fert) + pestisida nabati. Pada umur 8 minggu setelah tanam diaplikasikan POC untuk daun (SO-Kontan Fert) + pestisida nabati.

Variabel hama yang diamati ialah kelimpahan individu setiap spesies serangga hama pada setiap tanaman uji. Pengamatan dilaksanakan pada 3 minggu setelah tanam (MST) hingga 8 MST dengan interval satu minggu satu kali pengamatan. Tanaman pada setiap plot perlakuan diamati 
populasi serangganya sebanyak 21 tanaman. Sedangkan, penyakit diamati ialah penyakit layu bakteri dan layu fusarium dengan menghitung jumlah tanaman tomat yang berpenyakit, sehingga dapat ditentukan insidensi secara keseluruhan.

Data yang diperoleh berupa populasi hama di setiap tanaman sampel dan insidensi penyakit tanaman diolah dengan Excel. Indeks keanekaragaman Shannon Wiener dianalisis menggunakan program PAST. Hubungan pengaruh perlakuan dengan populasi serangga hama dan penyakit tanaman dilakukan dengan Uji F, dan dilanjutkan dengan analisis Duncan's Multiple Range Test (DMRT) pada taraf 5\% untuk perlakukan yang berbeda secara nyata.

\section{HASIL DAN PEMBAHASAN}

\section{Pengaruh Pestisida Nabati dan Metabolit Sekunder terhadap Hama Tanaman}

Secara keseluruhan dijumpai sebanyak 1.636 individu serangga hama pada pertanaman tomat dalam empat kali pengamatan. Semua hama yang dijumpai tergolong dalam 27 spesies, dari 17 famili dalam 6 ordo. Hemiptera menjadi ordo yang paling melimpah dibanding yang lainnya. Tidak hanya pada pertanaman tomat Ordo Hemiptera juga menjadi yang paling melimpah pada ekosistem sawah dengan berbagai teknik pengendalian hama (Afifah dan Sugiono, 2019).

Sedangkan pada Famili Alyerodidae, Kutu kebul Bemicia tabaci merupakan spesies serangga hama yang paling banyak dijumpai pada penelitian ini (Tabel 2). $B$. tabaci merupakan serangga penghisap cairan tanaman, dengan cara memasukkan stilet sebagai alat mulut yang membantu pengambilan makanan. Hama tersebut hampir dijumpai tidak hanya pada tanaman tomat, melainkan juga pada 27 spesies tanaman lainnya sebagai inang hama kutukebul yang terdiri atas 23 genus dari 13 famili tanaman (Hendrival $d k k$., 2011).

Selain B. tabaci terdapat T. tabaci dan M. persicae yang kelimpahannya terlihat paling dominan dibanding spesies yang lain (Tabel 2). T. tabaci merupakan serangga hama yang berikuran kecil yakni antara 0.5 - $5 \mathrm{~mm}$. Hama Thrip menyebabkan daun tomat berwarna keperakan dan menggulung sehingga menyebabkan terganggunya fotosintesis. Tingginya populasi thrips disebabkan karena sulitnya melakukan pengandalian hama tersebut. Kendala tersebut juga dijumpai pada penelitian Sugiyono $d k k$. (2014), yang menyatakan bahwa populasi nimfa dari hama Thrips sp. tidak berbeda secata nyata pada perlakuan Pengendalian Hama Terdapu (PHT) dan konvensional, bahkan pada perlakuan PHT populasi imago lebih tinggi secara nyata 
Tabel 2. Populasi lima spesies serangga hama yang paling melimpah

\begin{tabular}{|c|c|c|c|c|c|c|}
\hline Ordo & Famili & Spesies & $\mathrm{A}$ & $\mathrm{B}$ & $\mathrm{C}$ & Total \\
\hline Diptera & Agromyzidae & Liriomyza sativae & 14 & 6 & 15 & 35 \\
\hline \multirow[t]{2}{*}{ Hemiptera } & Alyrodidae & Bemicia tabaci & 308 & 279 & 255 & 842 \\
\hline & Aphididae & Myzus persicae & 48 & 48 & 39 & 135 \\
\hline Lepidoptera & Noctuidae & Spodoptera litura & 6 & 6 & 4 & 16 \\
\hline Thysanoptera & Thripidae & Thrips tabaci & 102 & 82 & 101 & 285 \\
\hline Total spesies & & & 11 & 13 & 17 & 20 \\
\hline Individu & & & 486 & 430 & 436 & 284 \\
\hline Indeks Shann & on ('H) & & 1,10 & 1,08 & 1,30 & 1,24 \\
\hline
\end{tabular}

dibandingkan dengan perlakuan konvensional. Sedangkan, $M$. persicae merupakan jenis kutu daun yang menghisap tanaman dengan stilet, seperti B. tabaci. Kutu daun $M$. persicasae merupakan spesies polifag yang menyebabkan kerugian signifikan melalui efek kerusakan secara langsung pada daun tanaman ataupun dengan transimisi virus (Sidauruk and Sipayung, 2018).

Terdapat tiga perlakuan yang dilakukan pada penelitian ini yang terdiri atas perlakuan gabungan pestisida nabati maja-gadung dan metabolit sekunder Trichoderma harzianum (A), perlakuan pestisida nabati maja-gadung (B), dan kontrol atau tanpa adanya perlakuan pestisida nabati dan metabolit sekunder (C). Berdasarkan nilai keanekaragaman Shanon Wiener, tanaman tanpa perlakuan (C) memiliki nilai yang lebih tinggi dibandingkan tanaman dengan perlakuan (A dan B). Hal ini menunjukkan bahwa terjadi tekanan populasi pada tanaman dengan perlakuan. Nilai keanekaragaman yang rendah menandakan adanya stres dari komunitas yang mengakibatkan munculnya ketidakstabilan (Sudarso dan Wardianto, 2015).

Tekanan populasi serangga hama pada tanaman tomat tersebut akibat dari adanya kandungan pada buah maja dan gadung yang dapat digunakan untuk membunuh serangga sebagai insektisida nabati. Secara umum insektisida nabati bekerja secara spesifik untuk merusak perkembangan serangga dari telur, larva, pupa, hingga mampu menghambat pergantian kulit, komunikasi serangga, reproduksi serangga betina, dan mengurangi nafsu makan, serta mengusir serangga (Syakir, 2011). Darmanto $d k k$. (2019) menjelaskan bahwa kombinasi dari ekstrak umbi gadung dan buah maja berperan sebagai racun perut dalam pencernaan.

Buah maja mengandung zat kimia saponin dan tanin (Bhar et al., 2019). Saponin dapat menghambat kerja enzim yang menyebabkan penurunan kerja alat pencernaan dan penggunaan protein (Ahdiyah dan Purwani, 2015). Selain itu, 
saponin juga mampu untuk merusak membran sel (Yunita dkk., 2009). Sedangkan, tanin dijelaskan oleh Pappa $d k k$. (2019) bahwa tanin mampu menghambat kerja enzim, penghilangan protein berikatan dengan lipid dan protein serta mengikat enzim protease sebagai katalisator protein menjadi asam amino yang diperlukan untuk pertumbuhan. Lebih lanjut, juga dapat menyebabkan terjadinya kekacauan pada sistem penghantaran impuls ke otot sebagai akibat adanya penumpukan asetilkolin sehingga otot kejang dan terjadi kelumpuhan (paralisis) kerja dari racun kontak. Tidak berbeda dengan saponin, tanin juga mampu untuk mengganggu pencernaan serangga karena tanin akan mengikat protein dalam sistem pencemaan yang diperlukan serangga untuk pertumbuhan sehingga proses penyerapan protein dalam sistem pencemaan menjadi terganggu (Yunita $d k k$., 2009).

Meskipun umbi gadung dapat dimanfaatkan sebagai bahan pangan, namun belum banyak dimanfaatkan oleh masyarakat karena mengandung racun seperti dioscorin dan HCN (Rosmeri dan Monica, 2013). Hasil kajian oleh Utami $d k k$. (2012) menunjukkan bahwa ekstrak umbi gadung memberikan pengaruh yang nyata terhadap mortalitas, menghambat aktivitas makan, dan pembentukan pupa ulat kantong (Pteroma plagiophleps Hampson). Iftita (2016) menjelaskan bahwa bahan aktif asam sianida (Alkaloid dioscorine) memberikan efek anticholinesterase. Lebih lanjut, Iftita menjelaskan bahwa anticholinesterase menyebabkan enzim cholinesterase mengalami fosforilasi dan menjadi tidak aktif. Ketidak aktifan tersebut menyebabkan hambatan proses degradasi asetilkolin sehingga asetilkolin terakumulasi di celah sinap. Akibatnya terjadi peningkatan transmisi rangsang yang menyebabkan otot pernapasan mengalami kontraksi berkelanjutan sehingga terjadi kejang otot pernapasan dan menyebabkan kematian serangga uji.

Namun demikian, hasil uji F pengaruh perlakuan terhadap populasi serangga hama menunjukkan bahwa tidak berbeda secara signifikan (Tabel 3). Hal tersebut menandakan perlakuan majagadung atau pun dengan tambahan metabolit sekunder tidak mampu untuk menekan populasi serangga hama dalam budidaya tanaman tomat secara organik. Hasil serupa juga dijumpai pada pengujian ekstrak buah maja dan umbi gadung untuk mengendalikan hama Spodoptera litura (Darmanto $d k k$., 2019). Pada penelitian tersebut kombinasi ekstrak umbi gadung dan ekstrak buah maja tidak efektif untuk pengendalian hama pada konsentrasi yang diuji, meskipun berpengaruh pada tingkat mortalitas larva ulat grayak. 
Tabel 3. Uji F pengaruh perlakuan terhadap populasi serangga hama

\begin{tabular}{cc}
\hline Perlakuan & Populasi serangga hama (Ekor) \\
\hline A & $121,5 \mathrm{a}$ \\
B & $107,5 \mathrm{a}$ \\
C & $109,0 \mathrm{a}$ \\
\hline
\end{tabular}

Keterangan: Angka yang diikuti huruf yang sama pada kolom "Populasi Serangga Hama" menunjukkan hasil yang tidak berbeda nyata berdasarkan Duncan Multiple Range Test pada $\alpha=5 \%$.

Dimungkin terdapat beberapa faktor yang menyebabkan hal tersebut terjadi, yakni 1) pemberian pestisida nabati buah maja dan gadung tidak mengenai hama utama secara langsung, sehingga hama yang tidak terkena pestisida tersebut mampu berpindah ke tanaman lain; 2) dosis pestisida nabati buah maja dan gadung kurang mampu untuk membunuh serangga; 3) jarak antar plot perlakuan terlalu dekat, sehingga penyemprotan pestisida antar plot saling terpengaruhi.

\section{Pengaruh Pestisida Nabati dan Metabolit Sukunder terhadap Penyakit Tanaman}

Terdapat dua jenis penyakit yang menjadi fokus pada penelitian budidaya tomat organik ini, yaitu penyakit layu fusarium dan penyakit layu bakteri. Penyakit layu fusarium adalah penyakit yang disebabkan oleh Fusarium spp. Fusarium spp. memiliki kisaran inang yang luas, keragaman morfologi dan sifat patogenisitas bervariasi (Sari $d k k$., 2017). Sedangkan, penyakit layu bakteri pada tomat adalah penyakit yang disebabkan Ralstonia solanacearum yang mampu bertahan bertahun-tahun di dalam tanah (Adeputri $d k k$., 2016). Tidak hanya menyerang tanaman tomat, $R$. solanacearum juga mampu menginfeksi 200 spesies tanaman dari 53 famili (Elphinstone, 2005).

Berbeda dengan hasil analisis pada populasi serangga hama, hasil uji $F$ pengaruh perlakuan terhadap banyaknya tanaman yang terinfeksi penyakit menunjukkan perbedaan secara nyata pada taraf uji 5\%, baik secara tunggal majagadung maupun gabungan maja-gadung dengan metabolit sekunder T. harzianum (Tabel 4).

Hal tesebut juga dapat dilihat dari tinggi persentase insidensi penyakit pada kontrol yang mencapai $13 \%$ terinfeksi Ralstonia sp. (Tabel 5). Diikuti perlakuan B yang terinfeksi $6 \%$ Ralstonia sp. dan pelakuan A yang terinfeksi masing-masing 2\% Fusarium sp. dan Ralstonia sp. Secara keseluruhan insidensi penyakit yang disebabkan oleh Ralstonia sp. lebih tinggi (21\%) pada kontrol, dibanding perlakuan B (6\%), dan perlakuan A (4\%). 
Tabel 4. Uji F pengaruh perlakuan terhadap jumlah tanaman yang terserang penyakit

\begin{tabular}{cc}
\hline Perlakuan & Tanaman Berpenyakit \\
\hline A & $1,0 \mathrm{a}$ \\
B & $1,5 \mathrm{a}$ \\
C & $5,0 \mathrm{~b}$ \\
\hline
\end{tabular}

Keterangan: Angka yang diikuti huruf yang sama pada kolom "Tanaman Berpenyakit" menunjukkan hasil yang tidak berbeda nyata berdasarkan Duncan Multiple Range Test pada $\alpha=5 \%$.

Tabel 5. Insidensi penyakit tanaman tomat

\begin{tabular}{ccc}
\hline Perlakuan & Fusarium sp. & Ralstonia sp. \\
\hline A & $2 \%$ & $2 \%$ \\
B & $0 \%$ & $6 \%$ \\
C & $1 \%$ & $13 \%$ \\
\hline
\end{tabular}

Hasil tersebut menunjukkan bahwa perlakuan maja-gadung dan metabolit sekunder T. harzianum telah menekan kemunculan dan menyebarnya penyakit dari satu tanaman ke tanaman lainnya. Kemungkinan tersebut karena adanya kandungan antimikroba dan antijamur untuk Fusarium udum pada buah maja (Patel et al., 2012), termasuk juga reaktif terhadap Fusarium oxysporum (Bhar et al., 2019). Adanya Pethroleum ether, Dichloromethane, Chlorofom, Ethanol mampu melawan bakteri gram positif dan negatif (Patkar et al., 2012). Aktivitas antimikroba terhadap strain gram negatif lebih tinggi dibandingkan dengan strai gram positif (Bhar et al., 2019). Namun demikian, belum ada yang menyebutkan bahwa maja-gadung digunakan untuk mengendalikan penyakit pada tanaman.

Beberapa penelitian menyebutkan bahwa aplikasi $T$. harzariumi yang dapat menekan serangan penyakit layu Fusarium dan meningkatkan kualitas buah pada tanaman. T. harzianum merupakan jamur yang efektif menekan jamur patogen tular tanah diantaranya $F$. oxysporum yang juga menyerang tanaman tomat. Penelitian yang dilakukan oleh Widyastuti et al. (2003) dan Widyastuti dan Hariani (2006) mengindikasikan bahwa Trichoderma efektif untuk menghambat patogen tular tanah seperti Sclerotium rolfsii, Fusarium sp., Rhizoctonia solani, dan F. oxysporum dengan berbagai mekanisme yaitu kompetisi, antibiosis, dan mikoparasit. $T$. harzianum membentuk koloni pada sistem perakaran, meningkatkan dan menyehatkan massa perakaran dan konsekuensinya terlihat menunjang peningkatan hasil panen serta adanya peningkatan kualitas buah, sedangkan pada aplikasi dengan fungisida kimia tidak menunjukkan fenomena yang demikian. Pada penelitian serupa formula $T$. harzianum-mikoriza $23,97 \mathrm{~g} / \mathrm{tan}$ mampu untuk menekan penyakit layu Fusarium, 
berpengaruh baik pada pertumbuhan tanaman jahe, bahkan mampu untuk menekan pemakaian pupuk $\mathrm{N}, \mathrm{P}$ dan $\mathrm{K}$ hingga 51,12\% dan pupuk daun 36,91\% dari dosis yang dianjurkan (Darini $d k k$., 2013). Hasil penelitian Latifah $d k k$. (2011) menunjukkan bahwa pemberian $T$. harzianum dapat meningkatkan pertumbuhan akar bawang merah hingga $57 \%$.

\section{KESIMPULAN}

Aplikasi pestisida nabati majagadung dengan atau tanpa penambahan $T$. harzianum belum mampu menekan populasi hama pada budidaya tomat secara organik secara signifikan. Meskipun demikian perlakuan pada aplikasi majagadung dengan atau tanpa penambahan $T$. harzianum telah mampu menekan penyakit layu fusarium serta penyakit layu bakteri secara signifikan.

\section{DAFTAR PUSTAKA}

Adeputri, E., Rustikawati, D. Suryati dan C. Herison. 2016. Penapisan tiga puluh tujuh genotipe tomat dan seleksi primer RAPD untuk toleransi terhadap layu bakteri (Ralstonia solanacearum). Akta Agrosia, 19(1):28-41.

Afifah, L. dan D. Sugiono. 2019. Fluktuasi populasi serangga pada lahan persawahan Kecamatan Pangkalan Kabupaten Karawang: Indikator untuk kesehatan lingkungan. Jurnal Ilmu Dasar, 20(1):1-6.
Ahdiyah, I. dan K.I. Purwani. 2015. Pengaruh ekstrak daun mangkokan (Nothopanax scutellarium) sebagai larvasida nyamuk Culex sp. Jurnal Sains dan Seni ITS, 4(2):2337-3520.

Alfizar, Marlin dan N. Hasanah. 2011. Upaya pengendalian penyakit layu Fusarium oxysporum dengan pemanfaatan agen hayati cendawan FMA dan Trichoderma harzianum. Jurnal Floratek, 6:8-17.

Bhar, K., S. Mondal and P. Suresh. 2019. An eye-catching review of Aegle marmelos L. (Golden Apple). Pharmacognosy Journal, 11(2):207224.

Darini, S.U., E. Rokhminarsi dan M. Januwati. 2013. Pengaruh formula Trichoderma Harzianum-Mikoriza dan pupuk inorganik terhadap serangan Fusarium oxysporum pada tanaman jahe muda. Agrin, 17(1):113.

Darmanto, I.W., D. Supriyatdi dan A. Sudirman. 2019. Pengendalian ulatgrayak (Spodoptera litura F.) dengan ekstrak ubi gadung dan ekstrak buah maja. Jurnal Agro Industri Perkebunan, 7(1):23-30.

Elphinstone, J.G. 2005. The current bacterial wilt situation: a global overview. In: Allen C, P. Prior, and A.C. Hayward. (eds.). Bacterial wilt disease and the Ralstonia solanacearum species complex, APS Press, St. Paul Minnesota, USA.

Ghorbani, R., V. Poozesh and S. Khorramdel. 2012. Tomato production for human health, not only for food. In: Lichtfouse E., $(E d)$. Organic Fertilisation, Soil Quality and Human Health, Springer, New York.

Hendrival, P. Hidayat dan A. Nurmansyah. 2011. Kisaran inang dan dinamika populasi Bemisia tabaci (Gennadius) (Hemiptera: Aleyrodidae) di 
pertanaman cabai merah. Jurnal Hama Penyaki Tumbuhan Tropika, 11(1):47-56.

Herlinda, S., Waluyo, S. P. Estuningsih dan C. Irsan. 2008. Perbandingan keanekaragaman spesies dan kelimpahan arthropoda predator penghuni tanah di Sawah Lebak yang diaplikasi dan tanpa aplikasi insektisida. Jurnal Entomologi Indonesia, 5(2):96-107.

Iftita, F. A. 2016. Uji efektivitas rendaman daun singkong (manihot utilissima) sebagai insektisida terhadap nyamuk Aedes aegypti dengan metode elektrik cair. Jurnal Kesehatan Masyarakat, $4(2): 20-29$.

Latifah, A., Kustantinah dan L. Soesanto. 2011. Pemanfaatan beberapa isolat $T$. choderma harzianum sebagai agensi pengendali hayati penyakit layu Fusarium pada bawang merah inplata. Eugenia, 17(2): 86-95.

Nurahmi, E., Susanna dan R. Sriwati. 2012. Pengaruh Trichoderma terhadap perkecambahan dan pertumbuhan bibit kakao, tomat, dan kedelai. Jurnal Floratek, 7:57-65.

Pappa, S., A.W. Jamaluddin dan A. Ris. 2019. Kadar tanin pada kulit buah kakao (Theobroma cacao L.) Kabupaten Poliwalimandar dan Toraja Utara. Cakra Kimia, 7(2): 92101.

Patel, P.K., J. Sahu, L. Sahu, N.K. Prajapati and B.K. Dubey. 2012. Aegle marmelos: A review on its medicinal properties. International Journal of Pharmaceutical and Phytopharmacological Research, 1(5):332-341.

Patkar, A.N., Desai N. V. and Ranage A.A. 2012. A review on Aegle marmelos: A potential medicinal tree. International Reseach Journal of Pharmacy, 3 (8):86-91.
Rosmeri, V.I. dan B.N. Monica. 2013. Pemanfaatan tepung umbi gadung (Dioscorea hispida Dennst) dan tepung MOCAF (Modified Cassava Flour) sebagai bahan substitusi dalam pembuatan mie basah, mie kering, dan mie instan. Jurnal Teknologi Kimia dan Industri, 2(2):246-256.

Rozi, Z.F., Y. Febrianti dan Y. Tela. 2018. Potensi sari pati gadung (Dioscorea hispida L.) sebagai bioinsektisida hama walang sangit pada tanaman padi (Oryza sativa L.). Jurnal Biogenesis, 6(1):18-22.

Sidauruk, L. and P. Sipayung. 2018. Population of Myzus persicae (Sulzer) and insect diversity on intercropping potatoes with other plants which planting at different time. IOP Conf. Series: Earth and Environmental Science, Medan, 1921 September 2018.

Sudarso, J. dan Y. Wardianto. 2015. Penilaian status mutu sungai dengan indicator makrozoobentos. Pena Nusantara, Bogor, INA.

Sugiyono, B.R., G. Mudjiono dan R. Rachmawati. 2014. Studi kelimpahan populasi Thrips sp. pada perlakuan pengelolaan hama terpadu dan konvensional pada tanaman cabai (Capsicum annuum L) di Desa Bayem Kecamatan Kasembon Kapubaten Malang. Jurnal Hama dan Penyakit Tumbuhan, 2(2):67-78.

Syakir, M. 2011. Status penelitian pestisida nabati. Pusat Penelitian dan Pengembangan Tanaman Perkebunan. Badan Litbang Pertanian. Seminar Nasional Pestisida Nabati IV, Jakarta, 15 Oktober 2011.

Utami, S. dan N.F. Haneda. 2012. Bioaktifitas ekstrak umbi gadung dan minyak nyamplung sebagai pengendali hama ulat kantong (Pteroma plagiophleps Hampson). Jurnal Penelitian Hutan Tanaman, 9(4):209-218. 
Widyastuti, S.M. dan M. Hariani. 2006.

Peranan Trichoderma reesei E.G.

Simmons pada pengendalian

Damping off semai Cendana

(Santalum album Linn.) Jurnal Perlindungan Tanaman Indonesia, 12(2):62-73.

Widyastuti, S.M., Harjono, Sumardi and D. Yuniarti. 2003. Biological control of Sclerotium rolfsii damping-off with three isolates of Trichoderma spp. Journal of Biology Sciences, 3(1):95102.

Yunita, E.A., N.H. Suprapti dan J.W. Hidayat. 2009. Pengaruh Ekstrak daun Teklan (eupatorium riparium) terhadap Mortalitas dan Perkembangan Larva Aedes aegypti. Bioma, 11(1):11-17. 